\title{
Isolation, Cultivation, and Morphological Characteristics of Hair Follicle Adult Stem Cells in the Bulge Region in Mouse and Human
}

\author{
Bélgica J. Molina ${ }^{1,2^{*}}$, Héctor J. Finol ${ }^{1}$ \\ ${ }^{1}$ Center for Electron Microscopy, Science Faculty, Central University of Venezuela, Caracas, Venezuela \\ ${ }^{2}$ Dermatology Service, University Hospital of Caracas, Caracas, Venezuela \\ Email: ‘belgikcel@gmail.com
}

How to cite this paper: Molina, B.J. and Finol, H.J. (2020) Isolation, Cultivation, and Morphological Characteristics of Hair Follicle Adult Stem Cells in the Bulge Region in Mouse and Human. Microscopy Research, 8, 9-30.

https://doi.org/10.4236/mr.2020.82002

Received: April 18, 2020

Accepted: April 27, 2020

Published: April 30, 2020

Copyright $\odot 2020$ by author(s) and Scientific Research Publishing Inc. This work is licensed under the Creative Commons Attribution International License (CC BY 4.0).

http://creativecommons.org/licenses/by/4.0/

\begin{abstract}
Skin contains various populations of stem cells (SCs). Among these are hair follicle stem cells (HFSCs) in the bulge region. The behavior of HFSCs deserves to be widely studied due to the benefits to be derived from their identification, isolation, and amplification. Skin samples of newborn mice $(\mathrm{n}=32)$ and human adults $(\mathrm{n}=10)$ were used, and the bulge region was isolated and cultured. The isolation and characterization of cells were conducted through immunocytochemistry and immunofluorescence, using mainly CD34 and CD200 monoclonal antibodies. Initially, cells grew slowly from the explant around the bulge region, accruing cells with different morphology in both mouse and human, latter being mostly polygonal; the mouse cells reaching confluence faster ( 5 to 7 days) than the human (12 to 15 days). It was possible to isolate into subcultures cells with small size (10 - $13 \mu \mathrm{m}$ diameter), round-shape, scant cytoplasm, central prominent nucleus and with nucleolus, which formed colonies, maintaining their phenotype in a high proportion ( $77 \%-83 \%$ and $91 \%$ in mouse and human, respectively), without showing changes in their morphology during almost 7 months in the mouse cells, and a month and a half in the human. These results demonstrate that the selection, the isolation, and the conditioned mediums allowed population increases of bulge cells and indicate that cultured cells may retain their sternness in that they maintained their phenotypic characteristics, expressed specific markers for SCs, and showed a high proliferative capacity for long periods. Hair follicles, in mice and humans, are important repositories of multipotent stem cells, due to their tendency to differentiate into keratinocytes. Human HFSCs, obtained by depilation, preserve their potential for proliferation and prove to be easily accessible. This suggests that the bulge cells may present an alternative source of autologous stem cells for tissue engineering and rege-
\end{abstract}


nerative medicine.

\section{Keywords}

Stem Cells, Hair Follicle, Bulge, Niche, Alopecia

\section{Introduction}

Stem cells (SCs) are characterized by their capacity to self-renew and their ability to differentiate into various cell lineages. Stem cells are classified by stage of development into embryonic, and adult stem cells. Adult stem cells are able to differentiate into all cell types. Currently, the main sources of stem cells are bone marrow, umbilical cord blood, and adipose tissue [1]. There is a need to find new and better stem cell sources that could facilitate therapeutic research.

Adult stem cells, as skin stem cells, have emerged as a source of interest for study and, could provide a cell bank with potential utility in regenerative medicine; for this, identification and isolation are necessary. The skin contains different populations of stem cells [2], localized into the interfollicular epidermis, the hair follicle, and the sebaceous glands. The stem cells govern tissue homeostasis and wound repair; they reside in the niche, or microenvironment, that hosts and maintains stem cells [3] [4] [5]. The hair follicles are self-renewing structures that cycle and reconstitute themselves throughout life. Each hair follicle perpetually goes through three stages: the rapid growth stage (anagen), apoptosis or involution stage (catagen), and rest stage (telogen) [6] [7]. Hair follicle stem cells (HFSCs) reside in a structure within the outer root sheath (ORS) of the hair follicle known as the "bulge", which acts as a reservoir of multipotent SC and, extends from the insertion point of the sebaceous gland duct to the attachment site for the arrector pili muscle [8] [9] [10] [11]. Stem cells, including HFSCs, never lose their regenerative ability if their niche is not destroyed. SCs exit the bulge and proliferate downward, creating a long linear trail of cells, the ORS [12].

From the anatomical point of view, the hair follicle has proven to be a challenge in both mice and humans [13] due to the lack of obvious anatomical features that can be visualized using light microscopy, the relatively small size of the hair follicles, and there being no universally adopted method to identify and isolate stem cells as a pure and viable population in culture [14] [15]. For this reason, I have focused on stem cells in the region of the prominence of the hair follicle, with great potential for proliferation.

These properties make them ideal candidates to be used in the regeneration of tissues such as skin and hair, or in the treatment of diseases such as alopecia. Our hypothesis states that a stem cell population resides in the bulge area and its maintenance is influenced by the microenvironment, if key factors are provided they can remain as undifferentiated adult stem cells with high potential for self-renewal. Therefore, determining the conditions that allow bulge cells to main- 
tain their phenotype and viability in vitro is necessary. The present investigation explores the in vitro isolation, culture and characterization of mouse and human HFSCs and specific markers; the differences between mouse and human hair follicles are also investigated.

\section{Methods}

\subsection{Tissue Samples}

Vibrissae follicles were obtained from the heads and bodies of newborn (2 to 3 day old) mice $(\mathrm{n}=32)$. All animals were acquired from the animal facility of the Instituto Nacional de Higiene Rafael Rangel. Also, excess healthy human scalp skin from was collected from 30 to 58-year-old facelift patients $(n=10)$, with the approval of the ethical committee of the Faculty of Sciences of the Universidad Central de Venezuela and written informed consent.

Additionally, human hair follicles samples were obtained from various regions of the body (face, legs and arms) from two volunteer donors, a 32-year-old female and a 37-year-old male; several hairs with full hair follicles were plucked. Anagen hair follicles and vibrissae were freshly dissected and divided into single hair follicle units under a microscope.

\subsection{Tissue Isolation and Cultivation}

The newborn mice were sacrificed, kept in $70 \%$ alcohol for $10 \mathrm{~min}$, and washed $2 \times$ for $5 \mathrm{~min}$ with phosphate-buffered saline (PBS). The tissues were trimmed into small pieces $(4 \mathrm{~mm} \times 4 \mathrm{~mm})$, and the skin fragments were incubated in $0.25 \%$ dispase II (Bacillus polymyxa, Gibco, BRL) in DMEM/F12 (1:1; Gibco-BRL) for $12-18 \mathrm{~h}$ at $4^{\circ} \mathrm{C}$. Scalp tissues were first rinsed in lactated Ringer's solution, and excess adipose tissue was removed. The hair follicles were squeezed out carefully in anagen phase, identified by the visible bulb and intact ORS, and carefully selected under the dissecting microscope. After two rinses with F-12, the follicles were transferred into a $35-\mathrm{mm}$ dish. Then the bulge region was amputated from the upper follicle by making two transverse cuts at the site of the enlargement spots of the ORS with a fine needle. All surgical procedures were performed in a sterile environment. After an additional two rinses, the bulges were transferred into a new dish at a density of 20 per dish, immersed in a Dulbecco's modified Eagle's medium (DMEM, Gibco) and Ham's F12 medium (3:1; Gibco), supplemented with $10 \%$ fetal bovine serum (FBS; Gibco), $10 \mathrm{ng} / \mathrm{ml}$ epidermal growth factor (Invitrogen), $5 \mathrm{~g} / \mathrm{ml}$ hydrocortisone, $5 \mathrm{~g} / \mathrm{ml}$ insulin (Sigma-Aldrich), $200 \mathrm{mmol} / \mathrm{L} \mathrm{L}$-glutamine (Gibco), and antibiotics (100 U/ml penicillin and $100 \mathrm{~g} / \mathrm{ml}$ streptomycin). The culture was incubated at $37^{\circ} \mathrm{C}$ and $5 \%$ $\mathrm{CO}_{2}$ in air, and the medium was changed twice a week. Human scalp tissues were first rinsed in lactated Ringer's solution and Ham's F12 with a double concentration of antibiotics (penicillin G, $100 \mu \mathrm{g} / \mathrm{ml}$ and, streptomycin, $100 \mu \mathrm{g} / \mathrm{ml}$ ). This solution was used as a transport medium to maintain aseptic conditions and optimal physiological conditions. Next, the samples were rapidly washed in 
$70 \%$ alcohol and were sectioned in the same way as the samples of mouse skin.

\subsection{Subculture and Amplification}

Colony formation was performed, after 3 - 4 days in primary culture; cells were collected by incubation with a $1: 1$ mixture of $0.125 \%$ trypsin (Sigma) and $0.02 \%$ EDTA (Sigma) for $5-10 \mathrm{~min}$ at $37^{\circ} \mathrm{C}$. The dispersed cells were centrifuged for 5 - $10 \mathrm{~min}$ at $2500 \mathrm{rpm}$ and replated in $35-\mathrm{mm}$ dishes coated with gelatin (mouse) and type I collagen (human) in tissue culture flasks with a medium change every 3 - 4 days. Cells were routinely passaged every 7 days. Every week, the cells were trypsinized (Gibco), and mass cultures were serially passaged until growth capacity was exhausted. For the sake of preservation, the cells were digested from culture dishes as described above.

After one rinse with culture medium, the cells were resuspended in $1 \mathrm{ml}$ fetal calf serum containing $10 \%$ dimethyl sulfoxide (Sigma), transferred into a cryotube, and placed into a freezer in a $4^{\circ} \mathrm{C},-20^{\circ} \mathrm{C}$, and $-80^{\circ} \mathrm{C}$ container by turns. In addition, some cells, after 24 h., were transferred into a liquid nitrogen tank in cryotubes.

\subsection{Determination of Growth Curve}

Cells which were characterized as rounded were plated into $4 \times 6$-well plates at a density of $1 \times 10^{-4}$ cells/well. After 2 days in culture, three wells were trypsinized (Gibco) and counted manually, using a Malassez chamber, at days 2, 4, 6, and 8. The growth curve was calculated from the mean cell number at each time point.

\subsection{Immunohistochemical Staining}

Cells, plated in 35-mm dishes, were washed $2 \times$ for 5 min with PBS and fixed in methanol for $5 \mathrm{~min}$. Peroxidase and nonspecific antibody binding were blocked by incubation with $1 \% \mathrm{H}_{2} \mathrm{O}_{2} /$ methanol and serum for $10 \mathrm{~min}$ at room temperature, followed by incubation with primary antibodies (anti-mouse CK15, clone LHK15; Thermo Fisher) in mouse and human, anti-mouse cluster of differentiation CD34 IgG (eBioscience) in mouse and anti-human CD200 IgG (eBioscience) in human, diluted 1:100 overnight at $4^{\circ} \mathrm{C}$ for $30 \mathrm{~min}$. The cells were then washed $3 \times$ for 5 min to remove unbound primary antibody and incubated with a secondary antibody (kit) for $10 \mathrm{~min}$ at $37^{\circ} \mathrm{C}$; unbound second antibody was removed by washing $3 \times$ for $5 \mathrm{~min}$ and visualized by DAB kit (Dako). Cells whose cytoplasm appeared brown were taken to be positive cells. Counterstaining with hematoxylin was performed when it was necessary to identify the bulge area.

\subsection{Immunofluorescence Staining}

Cells plated in $35-\mathrm{mm}$ dishes were washed $2 \times$ for 5 min with PBS and fixed in methanol for $5 \mathrm{~min}$ as above. Sections were blocked with $10 \%$ horse serum diluted 1:30, at room temperature for $25 \mathrm{~min}$, and then incubated with the first 
primary antibody (anti-mouse CK15 (Thermo, clone LHK15) in mouse and human, anti-mouse CD34 IgG (eBioscience) in mouse and anti-human CD200 IgG (eBioscience) in human, diluted 1:100 at room temperature for $90 \mathrm{~min}$. After three consecutive washes, they were incubated with the second primary antibody (goat anti-mouse IgG conjugated with FITC for CK15 in mouse and human, anti-Rat IgG biotin (eBioscience) in mouse, and anti-Mouse IgG biotin (eBioscience) in human), diluted 1:100 at room temperature for $30 \mathrm{~min}$. Slides were washed three times and then incubated with streptavidin PE (eBioscience) for 30 min for CD34 and CD200. Slides were then washed, counterstained, and treated with mounting medium containing DAPI (Vector Laboratories). Labeled cells were observed, using inverted microscopy enabled phase contrast and epifluorescence microscope (Axiovert 40, Zeiss).

In general, a descriptive analysis was made of the morphology of the observed cells, a semiquantitative analysis in which the intensity of the fluorescence reaction was evaluated (intense, moderate, mild) and a quantitative analysis in which the cells positive for DAPI, CD34, and CD200 were counted.

The quantitative analysis of the immunoreactions for CD34, CD200, and DAPI in the culture was carried out in the following way: After immunostaining, the cells that expressed a positive reaction for CD34 in mouse and CD200 in human were counted twice by the same observer. To do this, it is needed to take into account the superposition of $400 \times$ images that represent a total area equal to $0.0243 \mathrm{~mm}^{2}$, using the ImageJ program, in an immunofluorescence microscope according to the methodology used by Zurita et al. and Amoh et al. [16] [17]. The relationship between the diameter of the spherical cells of the hair follicle prominence region and the intensity of the fluorescence in the field records was studied according to the pattern of immunoreaction in the culture, classified as: small $=10-13 \mu \mathrm{m}$, medium $=14-16 \mu \mathrm{m}$, and large $=17-20 \mu \mathrm{m}$, and degree of fluorescence (mild, moderate, and intense), according to the modified methodology of Zurita et al. and Tiede et al. [16] [18].

\subsection{Cellular Cryopreservation and Thawing}

The cells of the hair follicle prominence were resuspended in the freezing medium composed of DMEM: F12, supplemented with $20 \%$ FBS and $10 \%$ glycerol and stored at $70^{\circ} \mathrm{C}$ for later use. To thaw the cells, the cryotubes were placed in $37 \%$ distilled water until the sample was solubilized and found in the nutrient base medium. Then, it was centered for 5 minutes, and the cell pellet was resuspended in the base medium and seeded in 4 -well plates (Nunc). The cells were counted in a Neubauer chamber, using Trypan blue exclusion dye.

Microcultures were seeded into 96-well plates at 0.5 to 1 cell/well, coated with $1 \%$ gelatin in (mice) and $1 \%$ collagen I (human) (BioCoat, BD Biosciences). Only wells containing a single cell were observed daily for proliferation. Culture medium was constituted as previously described. After 7 days, cultures were fixed with $70 \%$ ethanol and stained with eosin. 


\subsection{Statistical Analysis}

For evaluation of flow cytometry data, the paired Student's t-test was applied to compare the percentage of cell numbers or FSC values of subpopulations. The level of significance was taken as $\mathrm{p} \leq 0.05$.

The percentage of cells in the region of the prominence positive and negative for CD34 (in mouse) and CD200 (in human) was determined in relation to the total number of cells represented by cell nuclei labeled with DAPI, in which the observations and records of four fields in a period of time in an initial stage of culture (45 days in the mouse and 7 days in the human) and a final stage of the culture (210 days in the mouse and 45 days in the human), according to the modified methodology of Amoh et al. [17].

\section{Results}

\subsection{Isolation of the Hair Follicle}

Isolation of intact hair follicles was carried out through dermo-epidermal separation. The prominence region was evidenced better in human than in mouse follicles (Figures $1(\mathrm{~A})-(\mathrm{C})$ ). The surface of the culture plate was coated with 1\% gelatin (mice) and $1 \%$ collagen (human), allowing improved cell adhesion to the surface of the plate. Cells from the whisker and hair follicles from mice and hair follicles from the adult humans (scalp and by depilation) were in the primary cultures. Initially, cells grew slowly from the explant around the bulge region, the mouse cells showing differing morphologies (Figures 2(A)-(D)), and the human cells being mostly round small in size and polygonal (Figures $2(\mathrm{E})-(\mathrm{H})$ ), within 3 - 4 days after of explantation of the hair follicles; with other cell types accruing later. As the cells proliferated, they formed a monolayer, reaching confluence faster in mouse cells ( 5 to 7 days) than in the human (12 to 15 days), and the mouse cells developed more colony-forming units than did the human cells (Figure 2). The human cell population consisted mainly of epithelial-like cells, with polygonal shape and core with one or two nucleoli, organized sometimes in groups; mitotic figures were occasionally observed with possible intercellular unions similar to desmosomes (Figures 2(E)-(H)).

The most striking morphological features found in the early stages of cultivation of bulge cells were the appearance refractive cells, rounded-shape, small

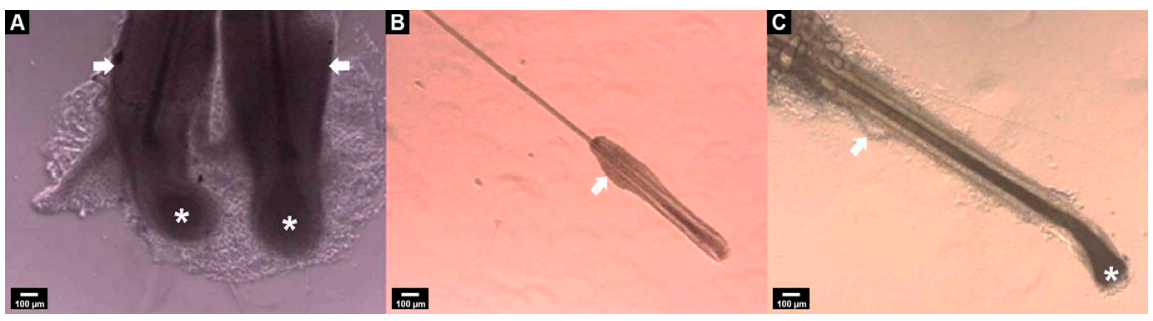

Figure 1. Explantation of the hair follicles. Phase contrast. The location of the bulge region (arrow) is shown. Vibrissae (A) and hair follicles (B) of mouse. Leg hair follicle (C) of human. Bulge region (arrow), bulb region (asterisk). 


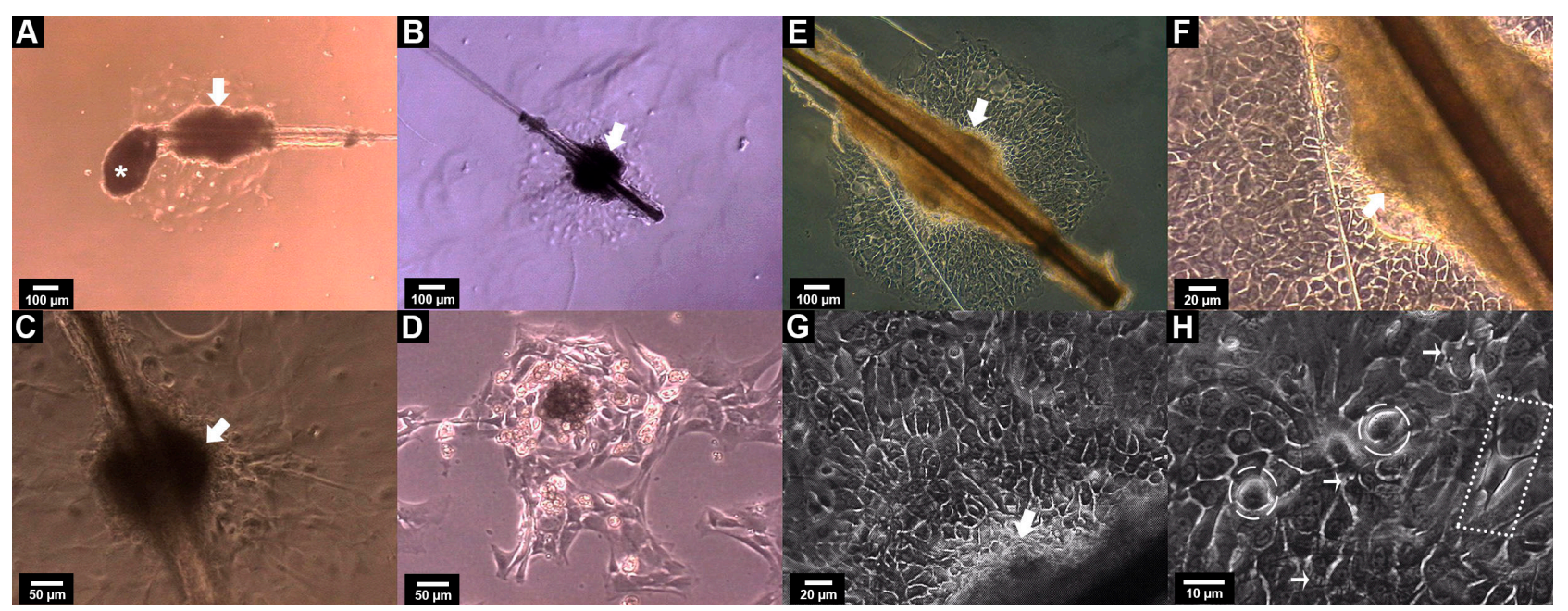

Figure 2. Primary culture of hair follicle stem cells in the bulge region of the mouse (A)-(D) and human (E)-(H). Phase contrast. (A)-(D) Micrographs showing cells growing from the explant in bulb region (asterisk) and bulge region (arrow) of vibrissa (A) with 4 days in culture, and showing small rounded cells that radiate around the bulb region (arrow) of hair follicle in the mouse (B)-(D) with 5 days of cultivation. (E)-(H) Human hair follicle cells reaching the confluence. Panoramic view of cells growing from the explant in the bulge region (arrow) (E) with 14 days of cultivation. Refractive, small and rounded cells are seen at the base of the follicle (arrow) (F), (G). Groups of polygonal cells (H) that show possible intercellular junctions (thin arrow), two dividing cells (circle) and one cell with cytoplasmic projections (rectangle).

size, with some of the cells positive for cytokeratin 15 (Figure 3(A)) and some positive for the stem cell marker CD34 (Figure 3(B), Figure 3(C)), in mouse cells, and CD200 (Figure 3(D), Figure 3(E)), in human. Other cell types were also visualized in smaller numbers, but always present. These, in order of frequency, were: fibroblast-like cells, mesenchymal-like cells, adipocyte-like cells, melanocyte-like cells, Langerhan-like cells, macrophage-like cells (Figure 3(B), Figure $3(\mathrm{C})$ ), and neuron-like cells (figure not shown). Overall, during the establishment of primary cultures, mouse cells were maintained for a period of 45 days and human cell for 30 days. A more heterogeneous population was seen among mouse cells than among human, without evidence of senescence, and the behavior of the cells showed spontaneous differentiation potential, so that the bulge cells captured do not represent a pure population.

\subsection{Isolation of the Bulge Region of the Hair Follicle}

After preliminary identification and harvesting of growing follicles, cells from the follicular bulge region of mice and humans were isolated and excised under a light microscope and placed into gelatin and collagen coated plates, for mouse and human cells, respectively. In the primary cultures, small, round cells prevailed. Enzymatic treatment of the processed follicles, yielded a cell population with the same phenotype in mouse (Figures 4(A)-(D)) and human cells (Figures 4(E)-(G)). Morphologically, these cells were observed, by light microscopy, to be refractive cells, round shaped, with prominent and euchromatic central nucleus and a nucleolus, and scant cytoplasm, about 10 to $15 \mu \mathrm{m}$ and a maximum $20 \mu \mathrm{m}$ in diameter, that could form colonies with cells in suspension 


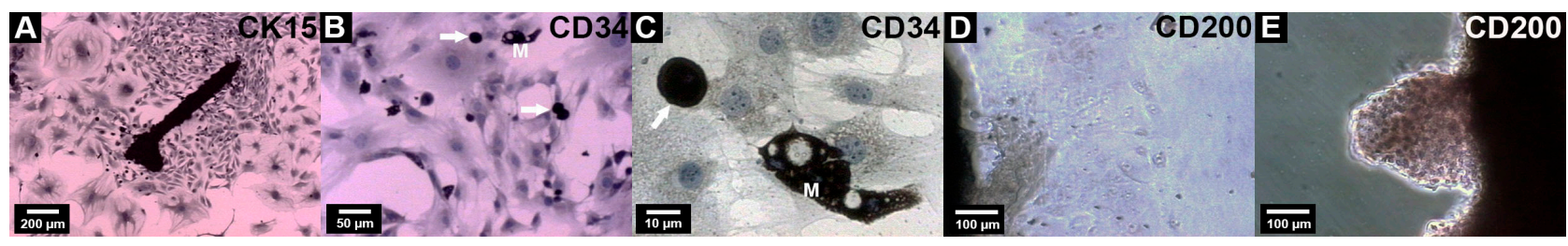

Figure 3. Immunocytochemical determination of $\mathrm{CK}_{1} 5^{+}, \mathrm{CD} 34^{+}$and $\mathrm{CD} 200^{+}$of the primary culture of hair follicle cells in mouse (A)-(C) and human (D) (E). (A) High expression CK15+ visible in small, rounded cells (arrows), moderate expression in fusiform cells and cells of variable size, with a slight expression in the periphery. (B) (C) High expression for CD34, unlike neighboring cells. Small, rounded cell, central nucleus, and scant cytoplasm (arrow). Irregularly contoured cells with vacuoles (M) that may correspond to macrophages. (D) (E) Expression of $\mathrm{CD}_{20} 00^{+}$in the bulge region, on the periphery apical to the follicle in contrast to the more distal polygonal cells in the explant.

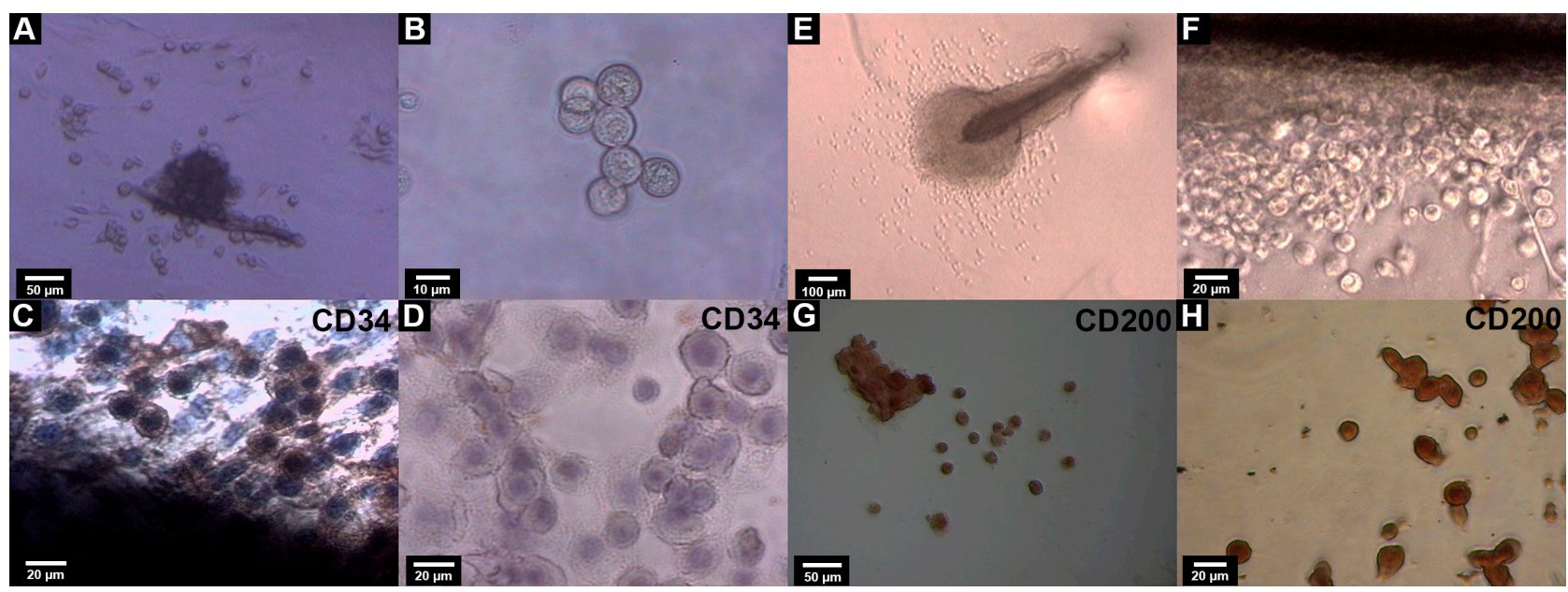

Figure 4. Isolation of the hair follicle stem cells in the bulge region of the mouse (A)-(D) and human (E)-(H) from the primary culture. (A)-(D) Rounded cells are shown growing in the bulge region with colony formation (B) Immunocytochemical determination of $\mathrm{CD}_{3} 4^{+}$in cells isolated from the prominence region of hair follicle (C), (D) (subcultures, 3rd passage, initial stage), colored nuclei with hematoxylin. (E)-(H) Small rounded cells, large nucleus, euchromatic, with little cytoplasm, forming a homogeneous population (7 days of cultivation). $\mathrm{CD} 200^{+}$expression in cells isolated from the bulge region of hair follicle (G), (H) (subcultures in initial stage of cultivation).

(Figure 4(B)). These cells were positive for CD34+ in mouse (Figure 4(C), Figure 4(D) and Figures 5(A)-(D)) and $\mathrm{CD}_{2} 200^{+}$in human (Figure 4(G), Figure $4(\mathrm{H})$ and Figures $5(\mathrm{E})-(\mathrm{H}))$.

Enzymatic digestion was performed with trypsin to amplify and homogenize the population. Some colonies were formed, visible in the first days of culture. These cells proliferated, and other cell types showed a tendency to decrease with time.

We also observed that subcultures considerably increased the cell population over generations and allowed the homogenization of the same, with a proliferative capacity greater in HFSCs (Figure 4(B), Figure 4(F), Figure 4(G), Figure 4(H); Figure 5, and Figure 6) (Table 1), maintaining the cultures for about 8 months in the mouse and 2 months in human cells, conserving their phenotype, and showing no features associated with senescence. However in human obtaining more homogeneous cell populations with rounded features of small size and scant cytoplasm were conducted and more easily accessible in follicles by depilation. 


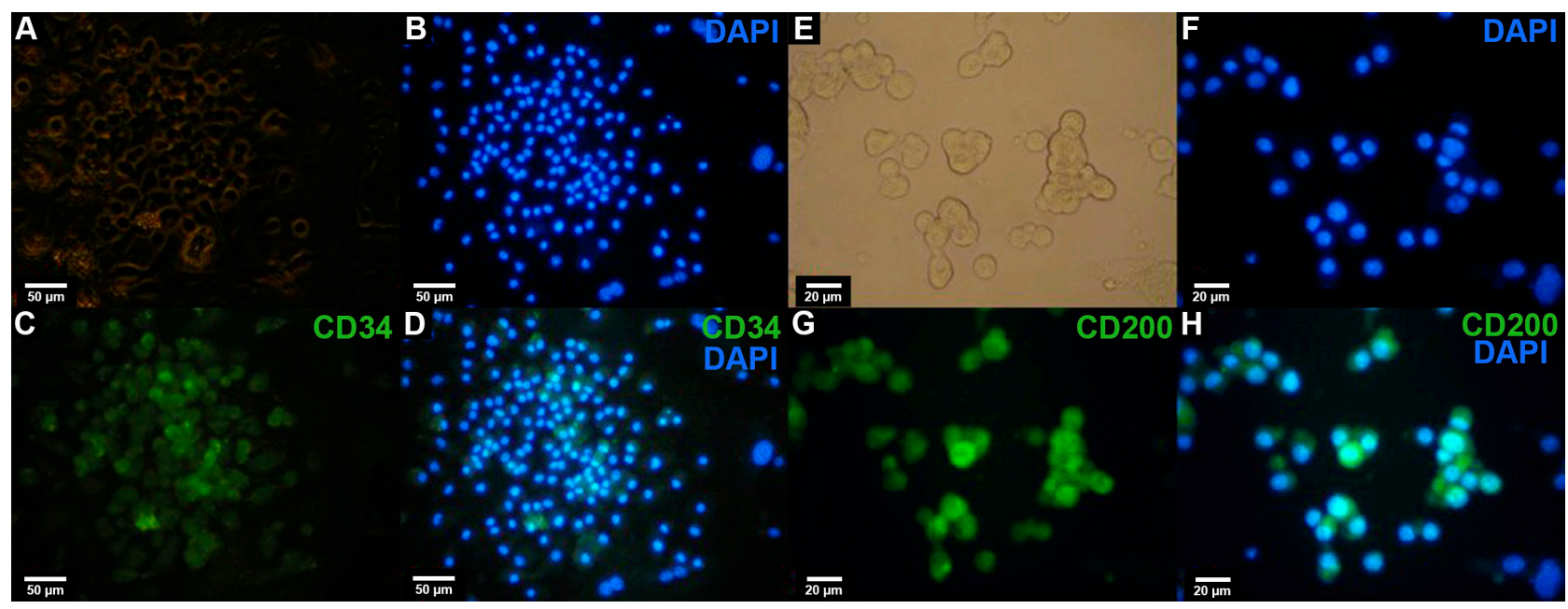

Figure 5. (A)-(H) Immunofluorescence staining showed colony-forming small, rounded CD $34^{+}$mouse cells (A)-(D) and CD200 ${ }^{+}$ human cells $(\mathrm{E})-(\mathrm{H})$ isolated from bulge region of hair follicles (initial stage of culture). Phase contrast view (A), (E), nucleated cells DAPI-associated blue fluorescence (B), (D), (F), (H) that contain either CD34 ${ }^{+}(\mathrm{C}),(\mathrm{D})$ or CD200 $(\mathrm{G}),(\mathrm{H})$ associated green fluorescence. 5 th passage, 3 days of cultivation (A)-(D), 2nd passage, 5 days of cultivation (E)-(H).

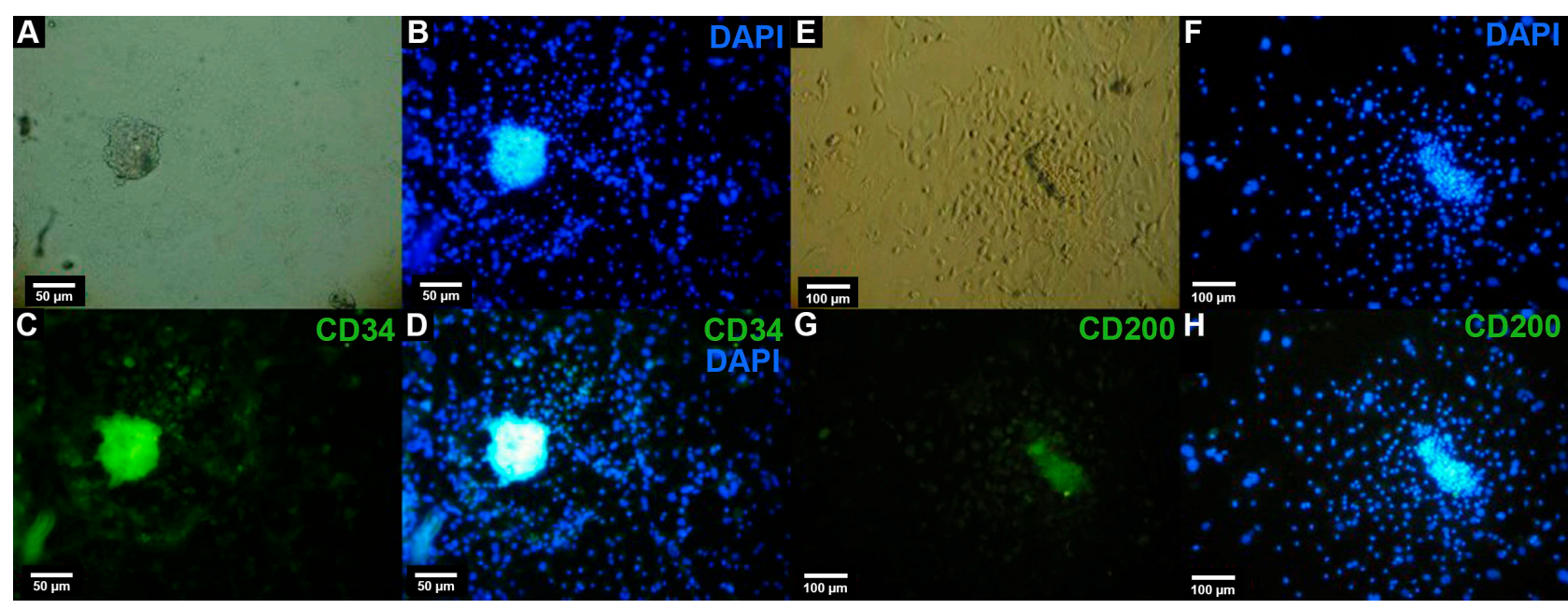

Figure 6. (A)-(H) Immunofluorescence staining showed colony-forming small, rounded CD34 mouse cells (A)-(D) and CD200 human cells $(\mathrm{E})-(\mathrm{H})$ isolated from bulge region of hair follicles (final stage of culture). Phase contrast view (A), (E), nucleated cells, DAPI-associated blue fluorescence (B), (D), (F), (H) that contain either CD34 ${ }^{+}(\mathrm{C}),(\mathrm{D})$ or CD200 ${ }^{+}(\mathrm{G}),(\mathrm{H})$ associated green fluorescence. 10th passage, 3 days of cultivation (A)-(D). 2nd passage, 10 days of cultivation (E)-(H).

Table 1. Summary of immunocytochemical staining patterns and immunofluorescence in primary cultures and subculture.

\begin{tabular}{|c|c|c|c|c|c|c|c|c|c|c|}
\hline & \multicolumn{6}{|c|}{ Immunocytochemical } & \multicolumn{4}{|c|}{ Inmunofluorescence } \\
\hline & \multicolumn{3}{|c|}{ Primary Culture } & \multicolumn{3}{|c|}{ Subculture } & \multicolumn{2}{|c|}{ Primary Culture } & \multicolumn{2}{|c|}{ Subcultivos } \\
\hline & CK15 & CD34 & CD200 & CK15 & CD34 & CD200 & CD34 & CD200 & CD34 & CD200 \\
\hline Control & - & - & - & - & - & - & - & -------- & - & ------- \\
\hline Mouse & ++ & ++ & - & $+/-$ & ++ & - & ++ & ------- & ++ & ------ \\
\hline Control & - & - & - & - & - & - & ------- & - & ------ & - \\
\hline Human & ++ & - & ++ & $+/-$ & - & ++ & ------ & ++ & ------ & ++ \\
\hline
\end{tabular}

Staining intensities are: $(-)$ no reaction, $(+/-)$ slightly positive staining, $(+)$ positive staining, and $(++)$ strong positive staining. 


\subsection{Analysis of the Cell Population of the Region of the Prominence of the Hair Follicle in Culture}

As to the relationship between spherical cell size and the degree of fluorescence of $\mathrm{CD}_{3} 4^{+}$and $\mathrm{CD} 200^{+}$antibodies, statistical studies indicate that there is an inverse relationship between cell size and the intensity of fluorescence $(\mathrm{p}<0.05)$ (Figure 7). Cells of smaller diameter $(10-13 \mu \mathrm{m})$ were more frequent and more intensely fluorescent.

Also, insulation efficiency of spherical cells was determined by comparing the number of $\mathrm{CD} 34^{+}$and $\mathrm{CD} 34^{-}$mouse cells and $\mathrm{CD} 200^{+}$and $\mathrm{CD} 200^{-}$human cells, per field, in the initial stages of culture (mouse, 45 days, and human, 7 days) and final stage of culture growth (mouse, 210 days, and human, 45 days) according to the kinetics of each culture (Figure 8). The percentage of $\mathrm{CD} 34^{+}$cells was $77.16 \%$ and $83.62 \%$, while for human cells, CD200 was $91.12 \%$ and $91.32 \%$, indicating a high proportion of cells positive for antibodies recognizing CMRPFP. After this time colonies of cells with morphology similar to adipose cells, were formatted, appeared, mainly among the mouse cells, with lipid droplets showing, positive in cytoplasmic staining with Sudan III (Figure 9).

\subsection{Determination of cell Proliferation}

\subsubsection{Growth Curve}

Mouse and human live cell number in the region of the hair follicle prominence recorded over time (Figure 10) determined an lag phase, showing very slow growth in the first 2 days after inoculating the cells and then increasing the proliferation exponential growth during the first 6 days of culture, after which mouse cells showed a decrease in proliferation and human cells showed no significant growth until day 8 culture.

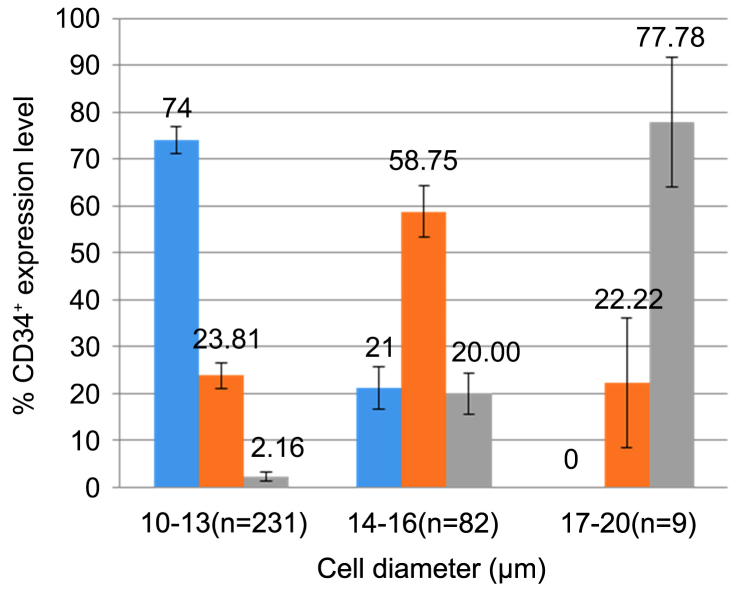

(A)

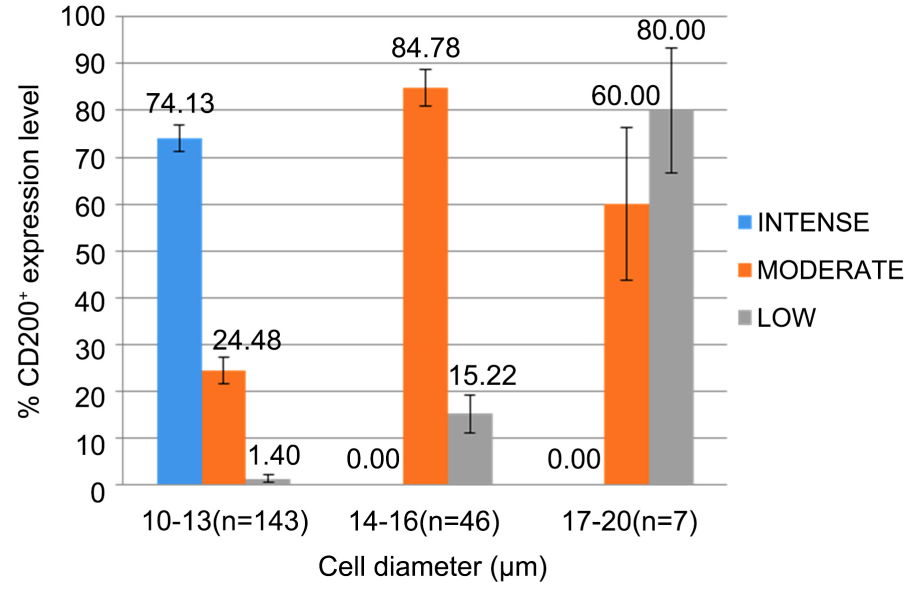

(B)

Figure 7. Percentages of cells isolated from the $\mathrm{CD} 34^{+}$mouse hair follicle (A) and $\mathrm{CD} 200^{+}$human hair follicle (B) in culture in relation to the size and degree of fluorescence. Size (small $=10-13 \mu \mathrm{m}$, medium $=14-16 \mu \mathrm{m}$ and large $=17-20 \mu \mathrm{m}$ ), degree of fluorescence (intense, moderate, and mild), ( \pm standard deviation) ( $\mathrm{n}=322$ mouse, $\mathrm{n}=196$ human). The significant differences ( $\mathrm{p}$ $<0.05)$, determined by $\chi^{2}$ tests, are indicated. 


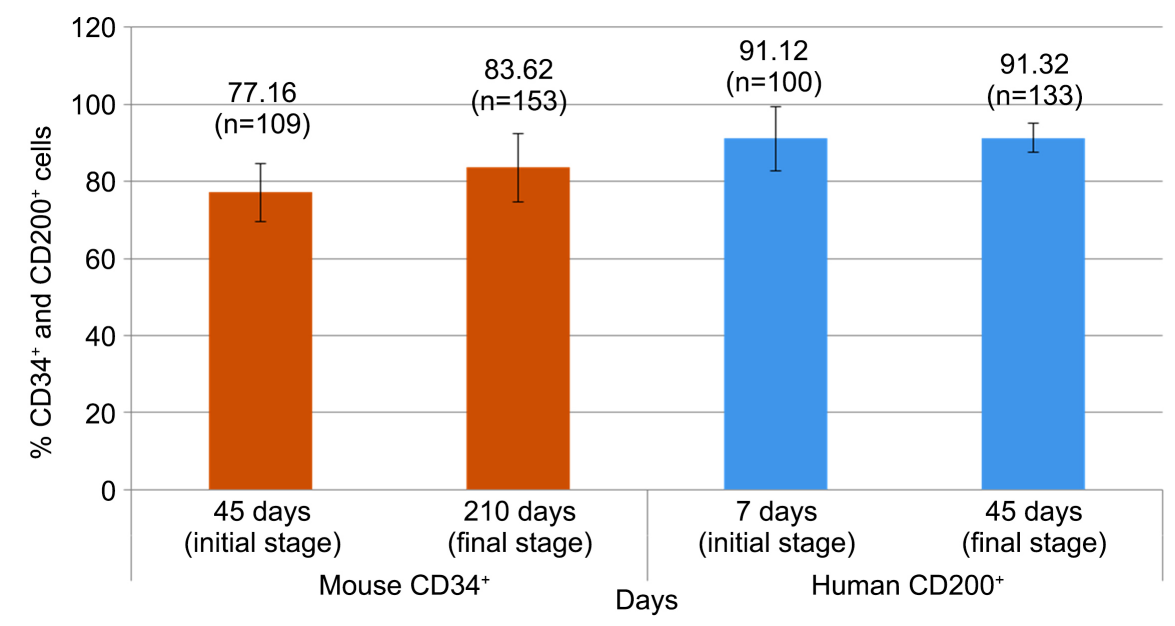

Figure 8. Percentage of $\mathrm{CD} 34^{+}$and $\mathrm{CD} 200^{+}$cells in the bulge region of the hair follicle (n $=5)$ ( \pm standard deviation) in relation to culture time. The significant differences $(\mathrm{p}<$ $0.05)$, determined by $\chi^{2}$ tests, are indicated.

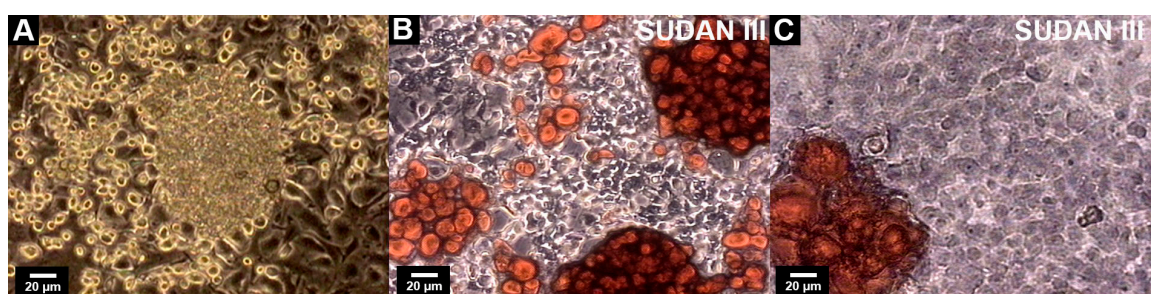

Figure 9. Evaluation with Sudan III staining in subcultures of cells of bulge region in mice (8 months). Phase contrast. (A)-(C) Amplification of the population of spherical cells with numerous inclusions in the cytoplasm. Phase contrast view (A). Colonies of cells that express a positive reaction to Sudan III (red) (B), (C), unlike the remaining neighboring cells, colored with hematoxylin $(C)$, that may correspond to adipocytes.

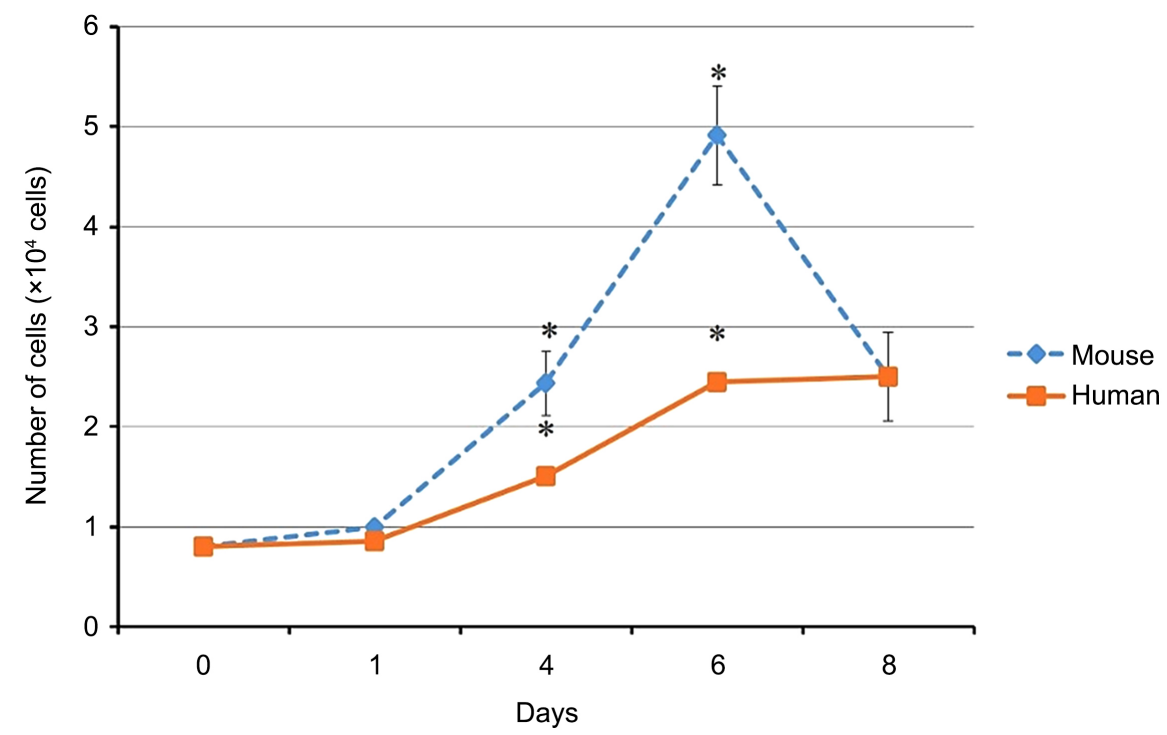

Figure 10. Growth curve of the cells of the prominence region of the hair follicle in mice and humans. It shows the number of viable cells as a function of time. The existence of significant changes ( $\mathrm{p}<0.05$, indicated with asterisk) was observed through a two-way ANOVA (time and species). Mouse $n=6$ and human $n=4$. 


\subsubsection{MTT Assays}

After 48 hours of incubation, we used the MTT method to measure cell viability (Figure 11). Moderate growth proliferation was observed for the first 4 days, followed by an exponential growth until the sixth day, after which a population decline and a decelerated tendency in proliferative speed was seen. The data indicate that viable cells behave similarly to the growth curve obtained above.

It is also known that there is a linear relationship between the absolute number of living cells in culture and the amount of metabolized MTT accumulated inside the cells released by adding DMSO. It could be seen in the pattern of the curve that the amount of metabolized MTT was different for each species. Significant differences $(\mathrm{p}<0.05)$ between the MTT metabolized in mouse and human were observed. Cultures of mouse cells generated more MTT formazan than in human.

The proliferation assays were consistent with the characteristic proliferative pattern of the cells in culture, between lag phase, exponential, or log phase, and stationary growth phases (Figure 10 and Figure 11) we found the time required to perform the subcultures in mice and in humans could correspond to 6 days.

\subsubsection{Cell Cryopreservation and Thawing}

Mouse cells, on the ninth and fifteen passage, were preserved by cryopreservation, maintaining morphology and proliferation capacity after 12 days of storage and subsequent thawing. They maintained their properties through recovery from storage, showing a homogeneous morphology (spherical) and testing positive for CD34 in mouse and CD200 in human cell expression (figure not shown). However, the human cells showed a small core.

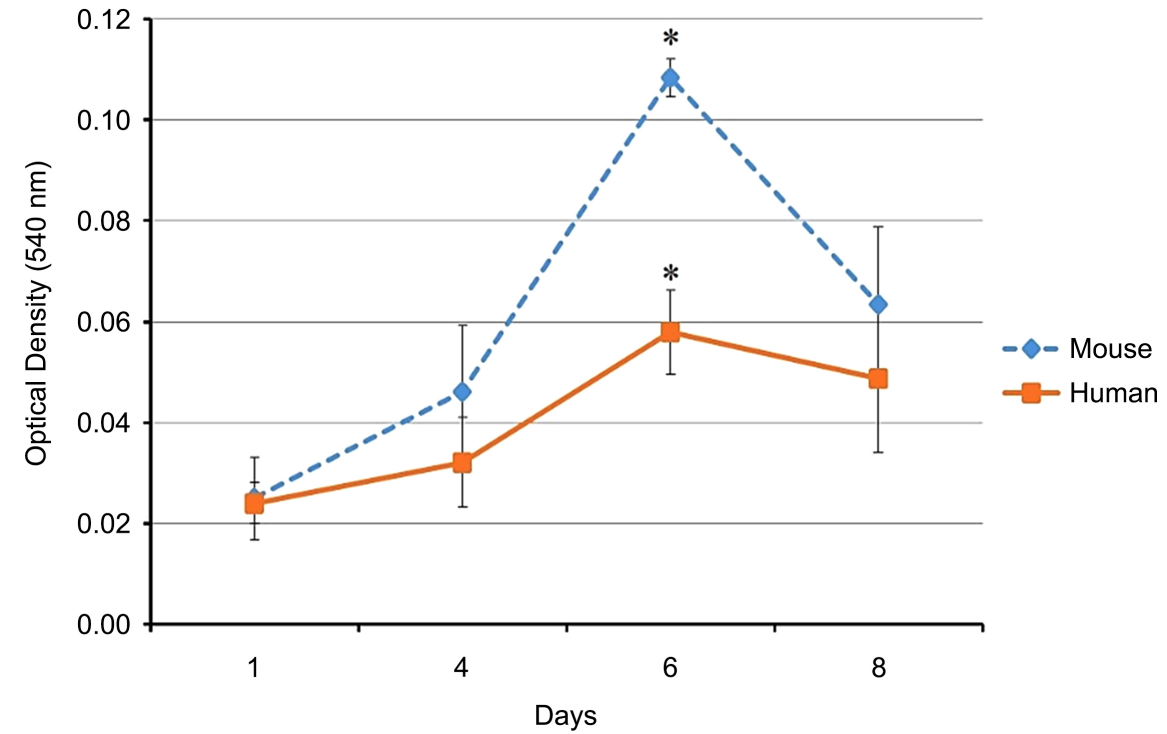

Figure 11. MTT test. The graph shows the proliferation percentages in the course of 8 days of cultivation. The existence of significant changes ( $p<0.05$, indicated with asterisk) was observed through a two-way ANOVA (time and species). Mouse $n=9$ and human $n$ $=4$, per day. 


\subsubsection{Culture of Isolated Clonal Cells in Prominence Region of Mouse Hair Follicle}

As it has been possible to confirm the importance of knowing the in vitro behavior of the CRPFP, a thorough analysis is needed to determine the properties of the cells. In view of the fact that $100 \%$ pure cultures cannot be obtained by the methods used, a method based on the cloning of cells showing the phenotype of interest was developed for which a clonal microculture was carried out, from dilution tests, to check the capacity of self-renewal and differentiation of cells isolated from mouse and human RPFP. This was observed in some wells with a single cell, per well, similar to the spherical cells noted above, which proliferated during the first 3 days after sowing and formed colonies. In the early days, cell divisions were observed at a small added, visible within 3 - 4 days in mouse cells, with formation of some spindle cells (figure not shown) and 6 days in human cells (figure not shown), after which proliferation gradually decreased.

\section{Discussion}

The present study allowed isolation, characterization, and amplification in vitro of $\mathrm{CD} 34^{+}$and $\mathrm{CD} 200^{+}$stem cells from hair follicles of mice and humans, respectively, as mostly pure and viable populations in culture; starting from the identification of bulge region stem cells from hair follicles [8] [9] [19] and development of a methodology [20]-[26] with modifications, fundamental pieces for the achievement of this work, highlythe importance of knowing the in vitro behavior of stem cells of hair follicles in mice and humans.

During the establishment of the primary culture of the entire hair follicle and vibrissae, several diverse phenotypes were seen, similar to native tissue. Growth of small, rounded, and refractory cells, $\mathrm{CD} 34^{+}$in mouse and $\mathrm{CD} 200^{+}$in human, in the protuberant region, was demonstrated, radiating in a monolayer consisting of a heterogeneous population 5 - 7 days in mice and 12 - 15 days in humans, consistent with previous reports [8] [9] [27] [28]. Among human follicles, the majority of cell appeared polygonal-looking, which may correspond to keratinocytes, similarly to what has been reported by other authors [24] [27] [29]. However, in the vibrissae, such populations are mainly heterogeneous with the predominance of fusiform cells; along the margins of the culture cells, we found various prolongations that may correspond to nerve cells and melanocytes among other cell types [28] [30] [31] [32] and in mouse follicles [9]. This distribution suggests that hair follicles in mice and humans represent an important repository of multipotent keratinocyte stem cells, more easily accessible in the human than in the mouse due to a tendency among the former to differentiate into keratinocytes, mainly.

Likewise, the presence of a heterogeneous population and the expressed proliferation potential may be due to the dermal tissue adhering to the mouse follicle, usually greater than in human, as well as culture medium and the age of the individuals, which are factors important in the growth and diversity of the cells present in the tissue and could justify these differences. 
Also, in culture of the bulb region of the hair follicle (dermal papilla), unlike the bulge region, in both mouse and human, we found that, from the explant, originated a heterogeneous cell population, with visible but scarce rounded cells, which may indicate the presence of a greater number of differentiated cells. All this would suggest that the manipulation and isolation of the cells of the prominence region is essential in order to avoid the growth of heterogeneous cell populations.

To corroborate the results obtained, the ICQ determination of the primary culture of intact mouse hair follicle cells showed a moderate expression of CK15 in rounded cells in addition to expression of CK15 in other cell types with morphology different from the stem cells, which correlates with previous IHQ results [19] and may indicate that CK15 is not an antibody specific for CM and that the cells isolated from the follicle do not represent a pure population of CM. Likewise, the small rounded cells could correspond to CM with a certain degree of differentiation. In this sense, they coincide with the expression of CK15 in primary human epithelial progenitor cells in situ and in vitro, indicated by [33]. In relation to ICQ and immunofluorescence, positive reaction was observed for CD34 in most rounded cells derived from mouse follicles and vibrissae and CD200 in human of RPFP, revealing that they can correspond to cells with characteristics of CM similar to what has been reported by other authors [4] [34] [35].

However, rounded cells that did not react to the antibody were observed, which could correspond to cells with a certain degree of differentiation. Additionally, positive expression was found for large cells of irregular contour and with possible vacuoles, which may correspond to macrophages [36] because CD34 antibody is also expressed in hematopoietic cells and its presence may be related to perifollicular macrophages contribution to the activation of skin epithelial stem cells [37].

Once we noted the origin of the proliferation of hair follicle cells in explants, we explored the growth potential and properties of the cells derived from the prominence region as a source of adult CM, performing a dissection of the region of the prominence as indicated by other authors [21] [29] [38], which allowed the isolation of cells; we were able to avoid contamination by other cell types by amplifying these cells in culture from a minimal number of follicles. For this, specific conditions of the culture medium were also required as growth factors supplied through subsequent subcultures by enzymatic disintegration with trypsin in order to obtain and maintain a homogeneous culture composed of cells with the same phenotype.

As a starting point for the development of the research and due to the scarce information available regarding the characterization of the CRPFP, this research describes the immunophenotype of cells of the bulge region as: spherical cells between 10 and $20 \mu \mathrm{m}$ in diameter, central nucleus rounded and prominent, of scarce refractory cytoplasm; characteristics that indicate a high activity of pro- 
tein synthesis, similar to the epidermal CM of the basal layer and to the cells described in other works [8] [29] [34]. We consider that, to obtain the spherical cells, a meticulous and exhaustive isolation of the RPFP is required; otherwise, the heterogeneous population obtained will be predominantly of spindle cells similar to the mesenchymal cells. In contrast, mesenchymal stem cells (CMM) from the dermal papilla of the bulb region of human hair follicles have been cultured and described as fusiform [39], being very different from the rounded cells in the bulge region described in this work.

Stem cells showed an inverse relationship between the size of the cells and the degree of fluorescence, which indicates a greater expression with smaller diameter $(10-13 \mu \mathrm{m})$ in both mouse and human cells $(\mathrm{p}<0.05)$, results that coincide with those described by Barrandon, and Green (1985) [40]. Likewise, these researchers point out that cells with a diameter between 10 and $12 \mu \mathrm{m}$ have a greater efficiency in the formation of colonies than $20 \mu \mathrm{m}$ cells [40], with colony formation efficiency being inversely proportional to the diameter of the cell and, with $\mathrm{CK} 15^{-}$and $\mathrm{CD} 200^{+}$cells smaller than $\mathrm{CK} 15^{+}$and $\mathrm{CD} 200^{+}$cells in humans [41].

On the other hand, in the subcultures, a remarkable increase of the cellular population was observed throughout the generations, which allowed their homogenization and the formation of colonies; these were characterized by a predominance of spherical cells, which maintained an undifferentiated phenotype. Results suggest that mainly cells with high proliferative capacity and differentiation potential are found in the prominence region, which is consistent with previous results [4] [8] [24] [27] [29] [42] [43].

From these results we consider that, in mice, the cell proliferation is greater than in human, which may be due to the age of the individuals, since this would influence the behavior of the cells in culture. It is known that, at a greater age of the patient, the ease of obtaining viable cells and their proliferation capacity decrease considerably [44]. In addition, the cumulative population is generally used as a biological age index, in which a greater proliferation potential could indicate that the cells are biologically younger than other adult cells [45].

Similarly, passages were made continuously, with a duration of 240 days in the mouse, an observation consistent with that of Nath et al. [46], who reported that these cells were cultivated continuously for more than 1 year (>100 passages) without changing their phenotype. In human cells, passages were made continuously, with a duration between 45 and 60 days, similar to the results obtained by $\mathrm{Oh}$ et al. [42], who demonstrated the possibility of cultivating CM from human hair follicles without causing significant changes in the phenotypes of the cells during 50 days of culture. This suggests that the phenotype of the cells is maintained over prolonged periods during culture [8] [43] [47] [48]. After this time (240 days in mice and 60 days in human), our results showed that colonies of cells formed with morphology similar to adipose cells, mainly among the mouse cells, with cytoplasm lipid droplets, showing positive cytoplasmic staining 
with Sudan III, which suggests a differentiation toward adipose cells and, may indicate the presence of different populations of $\mathrm{CM}$ in the niche of the prominence region or a differentiation of the cells toward the adipogenic lineage.

These results coincide with immunolabeling $(77.16 \%$ at 45 days in mouse and $91.12 \%$ at 7 days in human and $83.62 \%$ at 210 days in mouse and $91.32 \%$ at 45 days in human), which shows that the culture medium favored the isolation and proliferation of the spherical cells of the RPFP in mouse and human, without showing evidence of differentiation in the medium term. This may be due to the fact that this type of medium tends to lack factors that favor differentiation and may attenuate proliferative capacity [29] [42].

Among the outstanding properties, we find that the cells of the prominence region can grow in suspension and form colonies similar to those pointed out by $\mathrm{Yu}$, et al. [29]. In this regard, the International Society of Cell Therapy in 2006, proposed three criteria to define CMM [49]; however, criteria that define and classify the CMRPFP adequately have not yet been established.

Additionally, research on CM from the hair follicle indicates that most hair follicle samples have been derived from skins of the back of animals, or the human scalp by surgical means [43]. Therefore, human RPFP cell cultures, from male and female volunteer donors of 32 and 37 years of age, respectively, obtained by depilation of the chin, leg, and arm, were obtained, confirming that this method eliminates many of the problems associated with the isolation and manipulation shortening the procedure. These results were similar to those obtained by surplus tissue samples from plastic surgery procedures, achieving the isolation and amplification of the desired cell phenotype, preserving its potential for proliferation, and proving to be an easily accessible alternative.

In this context, in relation to the methodology, five key points were highlighted in the procedure: the dermo-epidermal separation; the manipulation and selection of hair follicles; adequate isolation of the prominence region; adequate adherence of the hair follicles to the plate and the use a culture medium that promotes the growth of cells.

During the dermo-epidermal separation, follicles and vibrissae were efficiently isolated. We recommend, the elimination of adipose and dermal tissue as much as possible because the thickness of the dermis influences enzymatic digestion, with disintegration being more effective if the biopsies are small, since the action of the dispase manages to penetrate better when acting at the level of the basement membrane to separate the bonds between the epidermis and the surrounding connective tissue; its cytotoxicity is also low in comparison to other enzymes allowing the follicles to be isolated [50].

Mouse follicles presented a prominent bulb, of smaller size that the vibrissae, and in both these regions, location is less evident. As it has been described in mice, it can be seen as a discrete protuberance, and in humans, it can be visualized as a clearly defined structure [8] [9] [19]. Human follicles, undoubtedly larger than those of mice, clearly showed the area of prominence, as described by 
Zhang et al., Ohyama, M., and Molina et al. [8] [9] [19]. Follicles in anagen phase were selected because the follicle is in a period of stimulated growth and the prominence region better evidenced as has been demonstrated with other methodologies [8] [25] [51] [52].

A substrate was required that promoted a strong adhesion of the cells to the support surface and was sufficiently inert to not influence the induction of differentiation in low proportions. We suggest using plates coated with $1 \%$ gelatin and $1 \%$ type I collagen for explants, facilitating the adhesion of intact follicles of mice and humans, respectively, providing a good grip and support compared to uncoated surfaces. The differences in cell growth between surfaces with and without coating are attributable to the weak binding of the cells to the uncoated surfaces [42]. Gelatin and collagen can facilitate the migration of cells that are in the outer zone of the explant and allow adequate growth of the population without obvious signals indicating induction of differentiation [8] [41]. However, according to the results obtained by Oh et al. [42] (who obtained a high level of cell population growth), another option to consider is to use surfaces coated with Matrigel.

\section{Conclusion}

In summary, these results support our hypothesis, demonstrate that the selection, the isolation and the conditioned mediums allowed the population increases of bulge cells and indicate that cultured cells may belong to the stem cells because they maintained their phenotypic characteristics, and expressed specific markers for SC, proving a high proliferative capacity for long periods. Detailed characterization allows us to identify them among other types of cells and evaluate its degree of differentiation according to size, with greater proliferation potential in both mouse and human cells. Human hair follicle stem cells in the bulge region cell cultures obtained by depilation preserve its potential for proliferation and prove to be an easily accessible alternative with more advantage, for being a non-invasive or painful procedure. This suggests that bulge cells may furnish an alternative source of easily accessible, autologous stem cells for tissue engineering and regenerative medicine.

\section{Acknowledgements}

The authors gratefully acknowledge the support provided by Dr. Karem Noris-Suárez at the Simón Bolívar University for loan of the fluorescence microscope. Dr. Gina Borgesat Central University of Venezuelafor their collaboration in provided some references. We thank the help of Dr. Gerald Schatten of the University of Pittsburgh for reviewing the manuscript.

\section{Conflicts of Interest}

The authors declare no conflicts of interest regarding the publication of this paper. 


\section{References}

[1] Weissman, I.L., Anderson, D.J. and Gage, F. (2001) Stem and Progenitor Cells: Origins, Phenotypes, Lineage Commitments, and Transdifferentiations. Annual Review of Cell and Developmental Biology, 17, 387-403. https://doi.org/10.1146/annurev.cellbio.17.1.387

[2] Abbas, O. and Mahalingam, M. (2009) Epidermal Stem Cells: Practical Perspectives and Potential Uses. British Journal of Dermatology, 161, 228-236.

https://www.ncbi.nlm.nih.gov/pubmed/19548960 https://doi.org/10.1111/j.1365-2133.2009.09250.x

[3] Botchkarev, V.A., Botchkareva, N.V., Nakamura, M., Huber, O., Funa, K., Lauster, R., Paus, R. and Gilchrest, B.A. (2001) Noggin Is Required for Induction of the Hair Follicle Growth Phase in Postnatal Skin. The FASEB Journal, 15, 2205-2214. https://www.ncbi.nlm.nih.gov/pubmed/11641247 https://doi.org/10.1096/fj.01-0207com

[4] Blanpain, C., Lowry, W.E., Geoghegan, A., Polak, L. and Fuchs, E. (2004) Self-Renewal, Multipotency, and the Existence of Two Cell Populations within an Epithelial Stem Cell Niche. Cell, 118, 635-648. https://www.ncbi.nlm.nih.gov/pubmed/15339667 https://doi.org/10.1016/j.cell.2004.08.012

[5] Yan, X. and Owens, D.M. (2008) The Skin: A Home to Multiple Classes of Epithelial Progenitor Cells. Stem Cell Reviews, 4, 113-118.

https://www.ncbi.nlm.nih.gov/pubmed/18491239 https://doi.org/10.1007/s12015-008-9022-4

[6] Schmidt-Ullrich, R. and Paus, R. (2005) Molecular Principles of Hair Follicle Induction and Morphogenesis. BioEssays, 27, 247-261.

https://www.ncbi.nlm.nih.gov/pubmed/15714560 https://doi.org/10.1002/bies.20184

[7] Yang, C.C. and Cotsarelis, G. (2010) Review of Hair Follicle Dermal Cells. Journal of Dermatological Science, 57, 2-11.

https://www.ncbi.nlm.nih.gov/pubmed/20022473

https://doi.org/10.1016/j.jdermsci.2009.11.005

[8] Zhang, Y., Xiang, M., Wang, Y., Yan, J., Zeng, Y., Yu, J. and Yang, T. (2006) Bulge Cells of Human Hair Follicles: Segregation, Cultivation and Properties. Colloids and Surfaces B. Biointerfaces, 47, 50-56.

https://www.ncbi.nlm.nih.gov/pubmed/?term=10.1016\%2Fj.colsurfb.2005.11.017 https://doi.org/10.1016/j.colsurfb.2005.11.017

[9] Ohyama, M. (2007) Hair Follicle Bulge: A Fascinating Reservoir of Epithelial Stem Cells. Journal of Dermatological Science, 46, 81-89. https://www.ncbi.nlm.nih.gov/pubmed/?term=10.1016\%2Fj.jdermsci.2006.12.002 https://doi.org/10.1016/j.jdermsci.2006.12.002

[10] Zouboulis, C.C., Adjaye, J., Akamatsu, H., Moe-Behrens, G. and Niemann, C. (2008) Human Skin Stem Cell and the Ageing Process. Experimental Gerontology, 43, 986-997. https://www.ncbi.nlm.nih.gov/pubmed/18809487 https://doi.org/10.1016/j.exger.2008.09.001

[11] Forni, M.F., Trombetta-Lima, M. and Sogayar, M.C. (2012) Stem Cells in Embryonic Skin Development. Biological Research, 45, 215-222.

https://doi.org/10.4067/S0716-97602012000300003 https://www.ncbi.nlm.nih.gov/pubmed/23283431

[12] Ito, M., Liu, Y., Yang, Z., Nguyen, J., Liang, F., Morris, R.J. and Cotsarelis, G. (2005) Stem Cells in the Hair Follicle Bulge Contribute to Wound Repair But Not to Ho- 
meostasis of the Epidermis. Nature Medicine, 11, 1351-1354.

https://www.ncbi.nlm.nih.gov/pubmed/16288281

https://doi.org/10.1038/nm1328

[13] Tiede, S., Kloepper, J., Bodo, E., Tiwari, S., Kruse, C. and Paus, R. (2007) Hair Follicle Stem Cells: Walking the Maze. European Journal of Cell Biology, 86, 355-376.

https://www.ncbi.nlm.nih.gov/pubmed/?term=10.1016\%2Fj.ejcb.2007.03.006 https://doi.org/10.1016/j.ejcb.2007.03.006

[14] Zhou, J., Jia, L., Yang, Y., Peng, S., Cao, Y. and Duan, E. (2004) Enrichment and Characterization of Mouse Putative Epidermal Stem Cells. Cell Biology International, 28, 523-529. https://doi.org/10.1016/j.cellbi.2004.04.007

[15] Jiang, S., Zhao, L., Purandare, B. and Hantash, B.M. (2010) Differential Expression of Stem Cell Markers in Human Follicular Bulge and Interfollicular Epidermal Compartments. Histochemistry and Cell Biology, 133, 455-465.

https://www.ncbi.nlm.nih.gov/pubmed/15261160 https://doi.org/10.1007/s00418-010-0684-Z

[16] Zurita, M., Aguayo, C., Oya, S. and Vaquero, J. (2007) Implicación de factores neurotróficos en la transdiferenciación neuronal de células madre mesenquimales adultas. Mpfre Medicina, 18, 201-208.

https://dialnet.unirioja.es/servlet/articulo?codigo=2470199

[17] Amoh, Y., Mii, S., Aki, R., Hamada, Y., Kawahara, K., Hoffman, R.M. and Katsuoka, K. (2012) Multipotent Nestin-Expressing Stem Cells Capable of Forming Neurons Are Located in the Upper, Middle and Lower Part of the Vibrissa Hair Follicle. Cell Cycle, 11, 3513-3517. https://doi.org/10.4161/cc.21803 https://www.ncbi.nlm.nih.gov/pubmed/?term=10.4161\%2Fcc.21803

[18] Tiede, S., Koop, N., Kloepper, J.E., Fässler, R. and Paus, R. (2009) Nonviral in Situ Green Fluorescent Protein Labeling and Culture of Primary, Adult Human Hair Follicle Epithelial Progenitor Cells. Stem Cells, 27, 2793-2803.

https://www.ncbi.nlm.nih.gov/pubmed/?term=10.1002\%2Fstem.213 https://doi.org/10.1002/stem.213

[19] Molina, B.J., Giansante, E. and Finol, H.J. (2018) Identification of Bulge Stem Cells in Mouse and Human Hair Follicles. Microscopy Research, 6, 19-29. https://doi.org/10.4236/mr.2018.63003

[20] Magerl, M., Kauser, S., Paus, R. and Tobin, D.J. (2002) Simple and Rapid Method to Isolate and Culture Follicular Papillae from Human Scalp Hair Follicles. Experimental Dermatology, 11, 381-385. https://www.ncbi.nlm.nih.gov/pubmed/12190949 https://doi.org/10.1034/j.1600-0625.2002.110414.x

[21] Xu, X., Lyle, S., Liu, Y., Solky, B. and Cotsarelis, G. (2003) Differential Expression of Cyclin D1 in the Human Hair Follicle. The American Journal of Pathology, 163, 969-978. https://www.ncbi.nlm.nih.gov/pubmed/12937137 https://doi.org/10.1016/S0002-9440(10)63456-6

[22] Sieber-Blum, M. and Hu, Y. (2008) Mouse Epidermal Neural Crest Stem Cell (EPINCSC) Cultures. Journal of Visualized Experiments, 9, e772.

https://www.ncbi.nlm.nih.gov/pubmed/19066583 https://doi.org/10.3791/772

[23] Nowak, J.A. and Fuchs, E. (2009) Isolation and Culture of Epithelial Stem Cells. Methods in Molecular. Biology, 482, 215-232.

https://www.ncbi.nlm.nih.gov/pubmed/19089359 https://doi.org/10.1007/978-1-59745-060-7_14

[24] Usovetskii, I.A., Burunova, V.V., Kovtun, N.E., Suzdal'tseva, Y.G., Krasil'nikova, 
Y.B., Korotkii, N.G. and Yarygin, K.N. (2009) Preparation of Mixed Keratinocyte and Melanocyte Cultures from Biopsy Specimens of Pigmented Skin Sites of Patients with Vitiligo Translated. Bulletin of Experimental Biology and Medicine, 148, 103-105. https://doi.org/10.1007/s10517-009-0646-4 https://www.ncbi.nlm.nih.gov/pubmed/?term=10.1007\%2Fs10517-009-0646-4

[25] Savkovic, V., Dieckmann, C., Milkova, L. and Simon, J.C. (2012) Improved Method of Differentiation, Selection and Amplification of Human Melanocytes from the Hair Follicle Cell Pool. Experimental Dermatology, 21, 948-950.

https://www.ncbi.nlm.nih.gov/pubmed/23171457 https://doi.org/10.1111/exd.12038

[26] Inoue, K. and Yoshimura, K. (2013) Isolation and Characterization of Human Hair Follicle Epithelial Cells. Methods in Molecular. Biology, 946, 411-421.

https://www.ncbi.nlm.nih.gov/pubmed/23179847 https://doi.org/10.1007/978-1-62703-128-8_26

[27] Wang, H.-T., Chen, B., Tao, K., Tang, C.-W. and Hu, D.-H. (2007) Human Hair Follicle Bulge Cells: Potential Germ Cells for Skin Tissue Engineering. Journal of US-China Medical Science, 4, 1-8. https://www.ncbi.nlm.nih.gov/pubmed/?term=10.4252\%2Fwjsc.v7.i4.711

[28] Blazejewska, E.A., Schlötzer-Schrehardt, U., Zenkel, M., Bachmann, B., Chankiewitz, E., Jacobi, C. and Kruse, F.E. (2009) Corneal Limbal Microenvironment Can Induce Transdifferentiation of Hair Follicle Stem Cells into Corneal Epithelial-Like Cells. Stem Cells, 27, 642-652. https://www.ncbi.nlm.nih.gov/pubmed/19074417 https://doi.org/10.1634/stemcells.2008-0721

[29] Yu, H., Fang, D., Kumar, S.M., Li, L., Nguyen, T.K., Acs, G., Herlyn, M. and Xu, X. (2006) Isolation of a Novel Population of Multipotent Adult Stem Cells from $\mathrm{Hu}$ man Hair Follicles. The American Journal Pathology, 168, 1879-1888.

https://www.ncbi.nlm.nih.gov/pubmed/16723703 https://doi.org/10.2353/ajpath.2006.051170

[30] Drewa, T., Joachimiak, R., Kaznica, A., Sarafian, V. and Sir, J. (2009) Primary Cultures from Rat Vibrissae as a Potential Cell Source for in Vitro Construction of Urinary Bladder Wall Grafts. Transplantation Proceedings, 41, 1932-1935.

https://www.ncbi.nlm.nih.gov/pubmed/19545759

https://doi.org/10.1016/j.transproceed.2009.02.091

[31] Nobakht, M., Najafzadeh, N., Safari, M., Roshandel, N.R., Delaviz, H., Joghataie, M.T., Bakhtiyari, M., Asalgoo, S. and Safar, F. (2010) Bulge Cells of Rat Hair Follicles: Isolation, Cultivation, Morphological and Biological Features. Yakhteh Medicine Journal, 1, 51-58.

[32] Hejazian, L.B., Esmaeilzade, B., Moghanni, G.F., Moradi, F., Hejazian, M.B., Aslani, A., Bakhtiari, M., Soleimani, M. and Nobakht, M. (2012) The Role of Biodegradable Engineered Nanofiber Scaffolds Seeded with Hair Follicle Stem Cells for Tissue Engineering. Iran Biomedical Journal, 16, 193-201. https://www.ncbi.nlm.nih.gov/pubmed/23183618

[33] Ramot, Y., Bíró, T., Tiede, S., Tóth, B.I., Langan, E.A., Sugawara, K., Foitzik, K., Ingber, A., Goffin, V., Langbein, L. and Paus, R. (2010) Prolactina Novel Neuroendocrine Regulator of Human Keratin Expression in Situ. FASEB Journal, 24, 1768-1779. https://www.ncbi.nlm.nih.gov/pubmed/?term=10.1096\%2Ffj.09-146415 https://doi.org/10.1096/fj.09-146415

[34] Amoh, Y., Li, L., Katsuoka, K., Penman, S. and Hoffman, R.M. (2005) Multipotent Nestin-Positive, Keratin-Negative Hair-Follicle Bulge Stem Cells Can Form Neu- 
rons. PNAS, 102, 5530-5534. https://doi.org/10.1073/pnas.0501263102 https://www.ncbi.nlm.nih.gov/pubmed/?term=10.1073\%2Fpnas.0501263102

[35] Liu, F., Uchugonova, A., Kimura, H., Zhang, C., Zhao, M., Zhang, L., Koenig, K., Duong, J., Aki, R., Saito, N., Mii, S., Amoh, Y., Katsuoka, K. and Hoffman, R.M. (2011) The Bulge Area Is the Major Hair Follicle Source of Nestin-Expressing Pluripotent Stem Cells Which Can Repair the Spinal Cord Compared to the Dermal Papilla. Cell Cycle, 10, 830-839. https://doi.org/10.4161/cc.10.5.14969 https://www.ncbi.nlm.nih.gov/pubmed/?term=10.4161\%2Fcc.10.5.14969

[36] Gartner, S., Liu, Y. and Natesan, S. (2012) De Novo Generation of Cells within Human Nurse Macrophages and Consequences Following HIV-1 Infection. PLoS ONE, 7, e40139. https://www.ncbi.nlm.nih.gov/pubmed/22911696 https://doi.org/10.1371/journal.pone.0040139

[37] Castellana, D., Paus, R. and Perez-Moreno, M. (2014) Macrophages Contribute to the Cyclic Activation of Adult Hair Follicle Stem Cells. PLoS Biology, 23, e1002002. https://www.ncbi.nlm.nih.gov/pubmed/?term=10.1371\%2Fjournal.pbio.1002002 https://doi.org/10.1371/journal.pbio.1002002

[38] Magerl, M., Kauser, S., Paus, R. and Tobin, D.J. (2002) Simple and Rapid Method to Isolate and Culture Follicular Papillae from Human Scalp Hair Follicles. Experimental Dermatology, 11, 381-385.

https://www.ncbi.nlm.nih.gov/pubmed/?term=10.1034\%2Fj.1600-0625.2002.110414.x https://doi.org/10.1034/j.1600-0625.2002.110414.x

[39] Wu, M., Sun, Q., Guo, X. and Liu, H. (2012) hMSCs Possess the Potential to Differentiate into DP Cells in Vivo and in Vitro. Cell Biology International Reports, 19, e00019. https://www.ncbi.nlm.nih.gov/pmc/articles/PMC3475446 https://doi.org/10.1042/CBR20120003

[40] Barrandon, Y. and Green, H. (1985) Cell Size as a Determinant of the Clone Forming Ability of Human Keratinocytes. PNAS, 82, 5390-5394.

https://www.ncbi.nlm.nih.gov/pubmed/2410922 https://doi.org/10.1073/pnas.82.16.5390

[41] Inoue, K., Aoi, N., Sato, T., Yamauchi, Y., Suga, H., Eto, H., Kato, H., Araki, J. and Yoshimura, K. (2009) Differential Expression of Stem-Cell-Associated Markers in Human Hair Follicle Epithelial Cells. Laboratory Investigation, 89, 844-856.

https://www.ncbi.nlm.nih.gov/pubmed/?term=10.1038\%2Flabinvest.2009.48 https://doi.org/10.1038/labinvest.2009.48

[42] Oh, J.H., Moheb, P., Farkas, D.L. and Tajbakhsh, J. (2011) Towards Expansion of Human Hair Follicle Stem Cells in Vitro. Cell Proliferation, 44, 244-253.

https://www.ncbi.nlm.nih.gov/pubmed/21535265 https://doi.org/10.1111/j.1365-2184.2011.00754.x

[43] Wang, X., Shi, Y., Zhou, Q., Liu, X., Xu, S. and Lei, T. (2012) Detailed Histological Structure of Human Hair Follicle Bulge Region at Different Ages: A Visible Niche for Nesting Adult Stem Cells. Journal of Huazhong University of Science and Technology Medical Science, 32, 648-656.

https://doi.org/10.1007/s11596-012-1012-8

https://www.ncbi.nlm.nih.gov/pubmed/?term=10.1007\%2Fs11596-012-1012-8

[44] Freshney, I.R. (2005) Culture of Animal Cells a Manual of Basic Technique. 5nd Edition, John Wiley \& Sons, Inc., Hoboken, 642. https://doi.org/10.1002/9780471747598

[45] Bruder, S.P., Jaiswal, N. and Haynesworth, S.E. (1997) Growth Kinetics, Self-Renewal, and the Osteogenic Potential of Purified Human Mesenchymal Stem Cells during 
Extensive Subcultivation and Following Cryopreservation. Journal of Cellular Biochemistry, 64, 278-294. https://www.ncbi.nlm.nih.gov/pubmed/9027588 https://doi.org/10.1002/(SICI)1097-4644(199702)64:2<278::AID-JCB11>3.0.CO;2-F

[46] Nath, M., Offers, M., Hummel, M. and Seissler, J. (2011) Isolation and in Vitro Expansion of Lgr6-Positive Multipotent Hair Follicle Stem Cells. Cell Tissue Research, 344, 435-444. https://doi.org/10.1007/s00441-011-1165-y https://www.ncbi.nlm.nih.gov/pubmed/?term=10.1007\%2Fs00441-011-1165-y

[47] Bajpai, V.K., Mistriotis, P. and Andreadis, S.T. (2012) Clonal Multipotency and Effect of Long-Term in Vitro Expansion on Differentiation Potential of Human Hair Follicle Derived Mesenchymal Stem Cells. Stem Cell Research, 8, 74-84. https://www.ncbi.nlm.nih.gov/pubmed/?term=10.1016\%2Fj.scr.2011.07.003 https://doi.org/10.1016/j.scr.2011.07.003

[48] Driskell, R.R., Juneja, V.R., Connelly, J.T., Kretzschmar, K., Tan, D.W. and Watt, F.M. (2012) Clonal Growth of Dermal Papilla Cells in Hydrogels Reveals Intrinsic Differences between Sox2-Positive and -Negative Cells in Vitro and in Vivo. Journal Investigative Dermatology, 132, 1084-1093.

https://www.ncbi.nlm.nih.gov/pubmed/?term=10.1038\%2Fjid.2011.428 https://doi.org/10.1038/jid.2011.428

[49] Beyer, N. and Da Silva, L. (2006) Mesenchymal Stem Cells: Isolation in Vitro Expansion and Characterization. In: Wobus, A.M. and Boheler, K.R., Eds., Stem Cells, Vol. 174, Handbook of Experimental Pharmacology, Springer-Verland, New York, 249-282. https://www.ncbi.nlm.nih.gov/pubmed/16370331 https://doi.org/10.1007/3-540-31265-X_11

[50] Vaissiere, C., Chevallay, B., Herbage, C. and Damour, G. (2000) Comparative Analysis of Different Collagen-Based Biomaterials as Scaffolds for Long-Term Culture of Human Fibroblasts. Medical \& Biological Engineering Computing, 38, 205-210. https://www.ncbi.nlm.nih.gov/pubmed/?term=10.1007\%2Fbf02344778 https://doi.org/10.1007/BF02344778

[51] Liu, Y., Lyle, S., Yang, Z. and Cotsarelis, G. (2003) Keratin 15 Promoter Targets Putative Epithelial Stem Cells in the Hair Follicle Bulge. Journal Investigative Dermatology, 121, 963-968.

https://www.ncbi.nlm.nih.gov/pubmed/?term=10.1046\%2Fj.1523-1747.2003.12600.x https://doi.org/10.1046/j.1523-1747.2003.12600.x

[52] Ohyama, M., Terunuma, A., Tock, C.L., Radonovich, M.F., PiseMasison, C.A. and Hopping, S.B. (2006) Characterization and Isolation of Stem Cell-Enriched Human Hair Follicle Bulge Cells. The Journal Clinical Investigation, 116, 249-260. https://www.ncbi.nlm.nih.gov/pubmed/16395407 https://doi.org/10.1172/JCI26043 